\title{
Implementasi Jaringan Saraf Tiruan Sebagai Alat Bantu Deteksi Bakteri Staphylococcus Aureus Pada Sayuran
}

\author{
Ali Rahmad Pohan \\ Program Studi Teknik Informatika, STMIK Budi Darma, Medan, Indonesia \\ Email: alirahmatp06@gmail.com
}

\begin{abstract}
Abstrak-Penelitian ini bertujuan untuk alat bantu deteksi Bakteri melalui citra bakteri pada sayuran untuk membantu mengidentifikasi bakteri Staphylococcus aureus pada sayuran. Masukan pada perangkat lunak adalah citra bakteri pada sayuran. Citra bakteri diolah dengan metode pengolahan citra grayscaling, thresholding dan segmentasi citra sehingga didapatkan ciri citra yang merepresentasikan bakteri pada pada sayuran. Salah satu teknik yang dapat digunakan sebagai alat bantu untuk mengamati bakteri Staphylococcus aureus adalah dengan menggunakan jaringan saraf tiruan dan mengkombinasikan dengan pengolahan citra. Jaringan saraf tiruan berfungsi sebagai pemrosesan informasi dengan menyimpulkan informasi dari data yang telahditerima dan sebagai pemberi keputusan terhadap data yang telah dipelajari. pengolahan citra adalah ilmu untuk memanipulasi gambar, yang melingkupi teknik-teknik untuk memperbaiki atau mengurangi kualitas gambar. Proses deteksi menggunakan perangkat lunak yang telah dibangun dapat dilakukan dengan baik. Proses tersebut dilakukan dengan mencocokkan nilai vector backpropagation cutra latihan dengan citra yang akan dideteksi.
\end{abstract}

Kata Kunci: Backpropagation, Bakteri, Citra.

\begin{abstract}
This study aims to aid bacterial detection through bacterial imagery in vegetables to help identify Staphylococcus aureus bacteria in vegetables. Input to the software is the image of bacteria in vegetables. Bacterial image is processed by grayscaling, thresholding and image segmentation processing methods so that the image characteristics that represent bacteria in vegetables are obtained. One technique that can be used as a tool to observe Staphylococcus aureus is to use artificial neural networks and combine them with image processing. Artificial neural networks function as information processing by inferring information from data that has been received and as a decision maker for data that has been studied. Image processing is the science of manipulating images, which includes techniques to improve or reduce image quality. The detection process using software that has been built can be done well. The process is carried out by matching the value of the exercise cutra backpropagation vector with the image to be detected.
\end{abstract}

Keywords: Backpropagation, Bacteria, Image.

\section{PENDAHULUAN}

Kemajuan teknologi komputer dapat diaplikasikan dalam bidang pendidikan. Hal ini dikarenakan teknologi komputer dapat dijadikan sebagai media pmebelajaran yang dapat digunakan oleh pendidik dalam proses pembelajaran. Salah satunya adalah untuk membantu dosen dalam mengidentifikasi bakteri secara cepat dan tepat dengan bantuan dari teknologi komputer.

Melalui proses belajar mengajar, dosen menempati posisi penting dan penentu berhasil tidaknya pencapaian suatu proses pembelajaran, sekaligus proses pembelajaran telah menggunakan berbagai model pendekatan dan metode yang lebih memberi peluang mahasiswa menjadi aktif, akan tetapi kedudukan dan peranan dosen tetap penting dan menentukan keterlibatan siswa secara aktif sangat ditentukan oleh kemampuan dosen dalam mengajar dan penggunaan metode mengajar.

Salah satu metode dalam pembelajaran yaitu dengan menggunakan media ICT, dimana media ICT pada saat ini merupakan media pendukung yang dapat menimbulkan rasa keingin tahuan yang tinggi dari masiswa terhadap matakuliah yang di ampu.

Jaringan syaraf tiruan merupakan salah satu cabang dari AI (Artificial Intellegence), adalah salah satu representasi buatan dari otak manusia yang selalu mencoba untuk mensimulasikan proses pembelajaran pada otak manusia. Istilah buatan ini diimplementasikan dengan menggunakan program komputer yang mampu menyelesaikan sejumlah proses perhitungan selama proses pembelajaran. Metode backpropagation merupakan salah satu metode yang digunakan dalam pembelajaran dari algoritma jaringan syaraf tiruan. Metode backpropagation memiliki tingkat keakuratan yang tinggi karena proses pelatihan yang dilakukan secara berulangulang sehingga menghasilkan nilai yang memiliki kesalahan yang sangat kecil. Metode pembelajaran backpropagation banyak digunakan untuk penyelesaian suatu masalah berkaitan dengan identifikasi, prediksi, dan pengenalan pola [2].

\section{METODE PENELITIAN}

\subsection{Bakteri}

Bakteri adalah salah satu golongan organisme prokariotik (tidak memiliki selubung inti). Bakteri sebagai makhluk hidup tentu memiliki informasi genetik berupa DNA, tapi tidak terlokalisasi dalam tempat khusus ( nukleus ) dan tidak ada membran inti. Bentuk DNA bakteri adalah sirkuler, panjang dan biasa disebut nukleoi. Pada DNA bakteri 
tidak mempunyai intron dan hanya tersusun atas akson saja. Bakteri juga memiliki DNA ekstrakromosomal yang tergabung menjadi plasmid yang berbentuk kecil dan sirkuler [1].

Staphylococcus aureus merupakan bakteri Gram positif berbentuk bulat berdiameter 0,7-1,2 $\mu$, tersusun dalam kelompok-kelompok yang tidak teratur seperti buah anggur, fakultatif anaerob, tidak membentuk spora, dan tidak bergerak. Bakteri ini tumbuh pada suhu optimum $37^{\circ} \mathrm{C}$, tetapi membentuk pigmen paling baik pada suhu kamar $\left(20-25^{\circ} \mathrm{C}\right)$. Koloni pada perbenihan padat berwarna abu-abu sampai kuning keemasan, berbentuk bundar, halus, menonjol, dan berkilau. Lebih dari $90 \%$ isolat klinik menghasilkan S. aureus yang mempunyai kapsul polisakarida atau selaput tipis yang berperan dalam virulensi bakteri. Berbagai derajat hemolisis disebabkan oleh S. aureus dan kadang-kadang oleh spesies stafilokokus lainnya [1].

\subsection{Pengolahan Citra}

Pengolahan citra adalah ilmu untuk memanipulasi gambar, yang melingkupi teknik-teknik untuk memperbaiki atau mengurangi kualitas gambar, menampilkan bagian tertentu dari gambar, membuat sebuah gambar yang baru dari beberapa bagian gambar yang sudah ada, dan beberapa teknik manipulasi gambar lainnya, pemrosesan citra, khususnya dengan menggunakan komputer, menjadi citra yang kualitasnya lebih baik [6].

\subsection{Jaringan Syaraf Tiruan}

Jaringan syaraf tiruan merupakan salah satu sistem pemrosesan informasi yang didesain dengan menirukan cara kerja otak manusia dalam menyelesaikan suatu masalah dengan melakukan proses belajar melalui perubahan bobot sinapsisnya. Jaringan syaraf tiruan mampu melakukan pengenalan kegiatan berbasis data masa lalu. Data masa lalu akan dipelajari oleh jaringan syaraf tiruan sehingga mempunyai kemampuan untuk memberikan keputusan terhadap data yang belum pernah dipelajari [10].

\subsection{Algoritma Backpropagation}

Backpropagation adalah salah satu model JST yang mempunyai kemampuan mendapatkan keseimbangan antara kemampuan jaringan untuk mengenali pola yangdigunakan selama pelatihan serta kemampuan jaringan untuk memberikan respon yang benar terhadap pola masukan yang serupa (tapi tidak sama) dengan pola yang dipakai selama pelatihan [15].

Backpropagation adalah sebuah metode sistematik untuk pelatihan multilayer jaringan syaraf tiruan. Metode ini memiliki dasar matematis yang kuat, obyektif dan algoritma ini mendapatkan bentuk persamaan dan nilai koefisien dalam formula dengan meminimalkan jumlah kuadrat galat error melalui model yang dikembangkan [16].

Adapun langkah- langkah algoritma pelatihan backpropagation adalah sebagi berikut [17]:

Langkah 0 : Inisialisasi bobot (sebaiknya diatur pada nilai acak yang kecil),

Langkah 1 : Jika kondisi tidak tercapai, maka lakukan langkah 2-9,

Langkah 2 : Untuk setiap pasangan pelatihan, langkah 3-8,

Tahap Perambatan Maju (forward propagation):

Langkah 3 : Tiap unit masukan $(x i, i=I, \ldots, n)$ menerima sinyal $x i$ dan menghantarkan sinyal ini ke semua unit lapisan diatasnya (unit tersembunyi),

Langkah 4 : Setiap unit tersembunyi $(x i, i=I, \ldots, p)$ jumlahkan bobot sinyal masukannya,

$z_{i n_{j}}=w_{0 j}+\sum_{i=1}^{n} x i v i j$

$V 0 j=$ bias pada unit tersembunyi $j$ aplikasikan fungsi aktivasinya untuk menghitung sinyal keluarannya, $z j=f$ (z_inj), dan kirimkan sinyal ini keseluruh unit pada lapisan diatasnya (unit keluaran).

perbaharui $w j k$

Langkah 5 : Tiap unit keluaran $(y k, k=I, \ldots, m)$ jumlahkan bobot sinyal masukannya,

$z_{i n_{k}}=w_{0 j}+\sum_{i=1}^{n} z i w i j$

$w 0 k=$ bias pada unit keluaran $\mathrm{k}$ dan aplikasikan fungsi aktivasinya untuk menghitung sinyal keluarannya, $y k=f$ $\left(y_{-}\right.$ink).

Tahap Perambatan Mundur (backward propagation):

Langkah 6: Tiap unit keluaran $(y k,=I, \ldots, m)$ menerima pola target yang saling berhubungan pada masukan pola pelatihan, hitung kesalahn informasinya,

$\delta k=(t k-y k) f 1\left(y \_\right.$ink $)$

Hitung koreksi bobotnya (digunakan untuk memperbaharui $w j k$ nantinya),

$\Delta W_{j k}=\alpha \delta k z j$

Hitung koreksi biasnya (digunakan untuk mem nantinya),

Langkah 7: Setiap unit lapisan tersembunyi $\left(z_{k},=l, \ldots, p\right)$ jumlahkan hasil perubahan masukannnya (dari unit-unit lapisannya),

$\Delta_{i n_{j}}=\sum_{i=1}^{n} \delta_{k} w_{j k}$

Kalikan dengan turunan fungsi aktivitasnya untuk menghitung informasi kesalahannya,

$\delta j=\left(\delta \_i n_{j}\right) f^{1}\left(z_{-} i n_{j}\right)$

Hitung koreksi bobotnya (digunakan untuk memperbaharui wjk nantinya), 
Tahap perubahan Bobot dan Bias:

Langkah 8 : Tiap unit keluaran $(y k, k=I, \ldots, m)$ update bobot dan biasnya $(\mathrm{j}=0 \ldots, p): w j k($ baru $)=V j k($ lama $)+$ $\Delta w j k$ Tiap unit lapisan tersembunyi $(z j, j=l, \ldots, p)$ update bias dan bobotnya $(I=0 \ldots n)$ :

$V($ baru $)=V i j($ lama $)+\Delta V i j$

Langkah 9 : Test kondisi berhenti. Test kondisi berupa epoch sudah mencapai jumlah epoch maksimal atau MSE sudah mencapai target error.

Rumus Mean Square Error (MSE):

$M S E=\frac{\sum_{i=1}^{n} e_{i}^{2}}{n}$

Mean Square Error (MSE) adalah fungsi kinerja yang sering digunakan untuk backpropagation yang dimana fungsi ini akan mengambil rata-rata kuadrat error yang terjadi antara output jaringan dan target.

\section{HASIL DAN PEMBAHASAN}

Pengetahuan dan pemanfaatan citra digital berkembang pesat, tidak saja di bidang kedokteran, industri manufaktur, dan kesehatan, tetapi juga di bidang mikrobiologi untuk mengidentifikasi bakteri Staphylococcus aureus pada sayuran. Dari ilmu pengetahuan tersebut memungkinkan kita dapat menerapkannya ke dalam sebuah program yang berbasis komputerisasi yang digunakan untuk mengidentifikasi bakteri Staphylococcus aureus pada sayuran yang termasuk kedalam bidang mikrobiologi secara lebih efektif dan efisien. Pemeriksaan pada umumnya dilakukan dengan cara melihat langsung dari media yang tersedia. Penglihatan manusia harus secara tepat dapat melihat objek dari bakteri. Secara kasat mata, seorang manusia tanpa perlu pengetahuan yang khusus dapat mengidentifikasi jenis-jenis bakteri berdasarkan bentu, warna, elefasi, tepi dan media tumbuh. Biasanya, mereka hanya berbekal pengalaman dan pengetahuan yang diperoleh sebelumnya. Akan tetapi penglihatan manusia pun mempunyai keterbatasan bahwa mata manusia pun akan mengalami kelelahan apalagi menghadapi bakteri yang berukuran kecil.

Analisa Implementasi Jaringan Saraf Tiruan Sebagai Alat Bantu Deteksi Bakteri Staphylococcus Aureus Pada Sayuran yaitu terdiri dari tampilan implemetasi input program dan output yaitu tampilan menu utama program, tampilan menu latihan JST untuk melakukan latihan citra bakteri yang akan disimpan didalam database dan tampilan menu deteksi untuk melakukan deteksi citra bakteri dengan kecocokan citra yang berada pada database saat proses latihan. Adapun tampilan program aplikasi menggunakan software VisualBasic 2008 sebagai berikut :

1. Tampilan Menu Utama

Tampilan menu utama adalah tampilan program yang akan muncul pertama kali ketika user membuka dan menjalankan aplikasi. Adapun tampilan aplikasi menu utama yang telah dibangun adalah sebagai berikut :

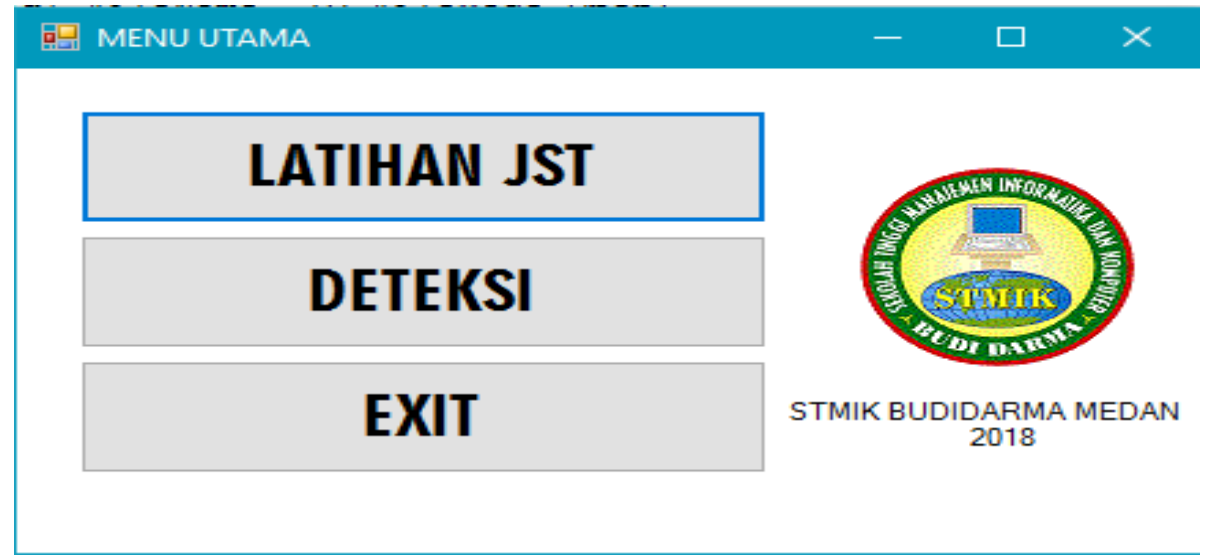

Gambar 1. Tampilan Menu Utama

Berdasarkan pada gambar di atas, tampilan menu utama memiliki beberapa sub menu diantaranya adalah menu "Latihan JST", menu "Deteksi" dan menu "Exit". Menu Latihan JST digunakan untuk proses penyimpanan citra bakteri sesuai dengan jenis bakterinya kedalam database aplikasi yang kemudian akan dicocokan dengan citra inputan pada saat akan dilakukan deteksi bakteri. Menu deteksi adalah menu yang digunakan user untuk melakukan deteksi bakteri dengan menginputkan citra bakteri baru. Menu exit digunakan untuk keluar dari aplikasi.

2. Tampilan Menu Latihan JST

Tampilan menu latihan JST adalah tampilan yang digunakan user untuk melakukan latihan pendeteksian bakteri yang akan disimpan didalam database aplikasi. Adapun tampilan menu latihan JST yang telah dibangun bersesuain dengan rancangan pada bab sebelumnya dapdat dilihat pada gambar di bawah ini : 


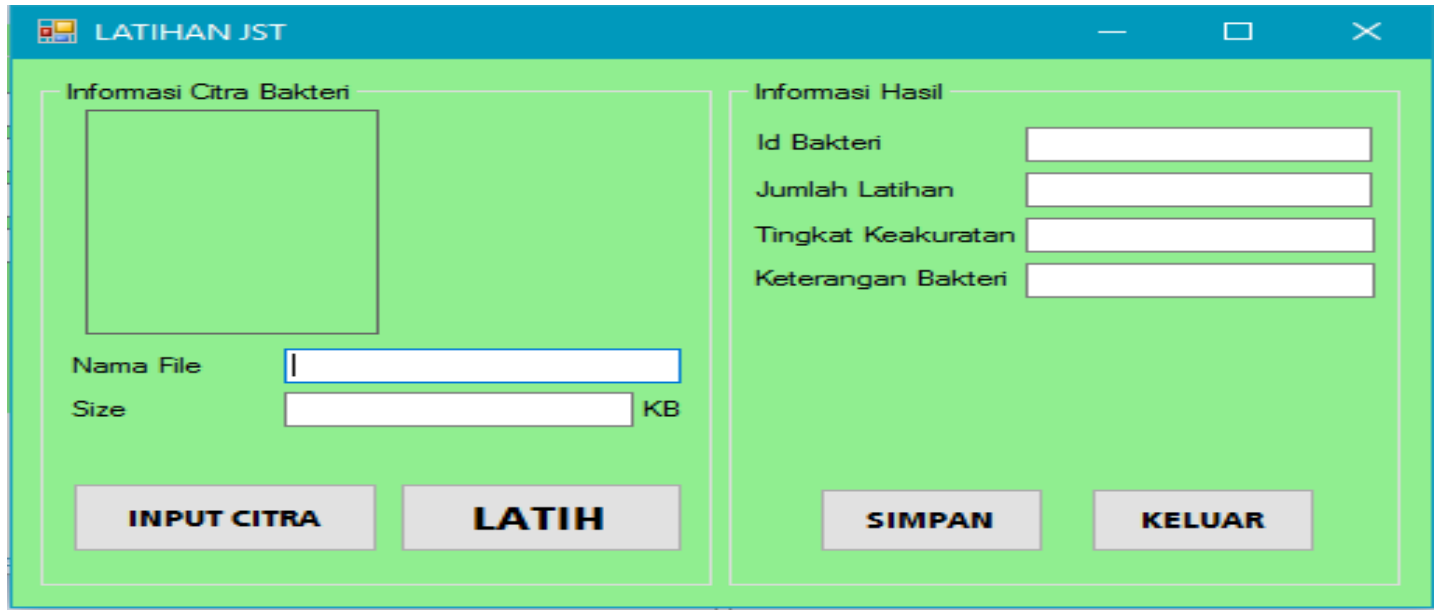

Gambar 2. Tampilan Menu Latihan JST

Berdasarkan pda gambar di atas, untuk memilih citra yang akan dilatih dan disimpan kedalam database dilakukan dengan menekan tombol "INPUT CITRA". Button "LATIH berfungsi untuk melakukan deteksi bakteri dan menampilkan keterangan hasil. Button "SIMPAN" berfungsi untuk menyimpan citra hasil pelatihan sesuai dengan keterangan yang dihasilkan di dalam database aplikasi. Adapun proses tersebut dapat dilihat di bawah ini :

a. Input Citra

Proses pertama yang dilakukan untuk latihan JST adalah menginputkan citra bakteri yang akan dilatih dan disimpan kedalam database. Adapun proses tersebut dapat dilihat pada hasil di bawah ini:

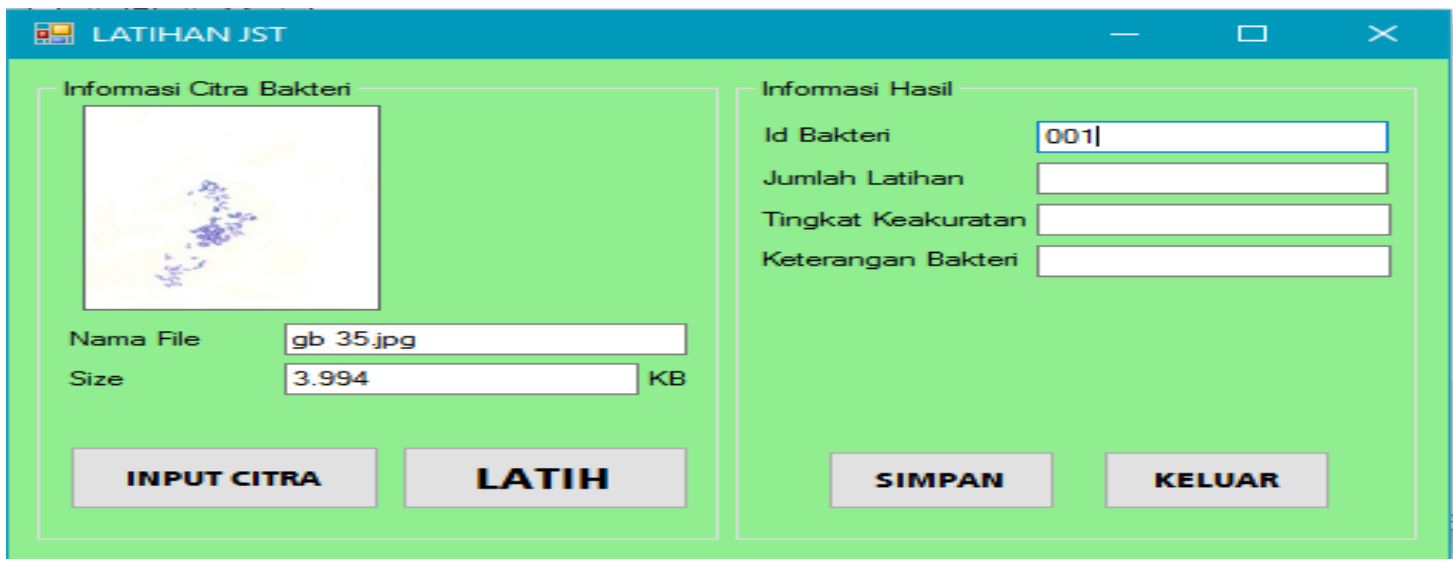

Gambar 3. Tampilan Input Citra Latihan

Berdasarkan pada gambar di atas, untuk memasukan citra latihan yang akan disimpan kedalam database dilakukan dengan menekan button "INPUT CITRA". Ketarangan yang didapat adalah nama file citra dan ukuran. Id bakteri diinputkan manual oleh user.

b. Proses Latihan JST

Proses selanjutnya adalah memilih button"LATIH" untuk mendeteksi tingkat keakuratan dan keterangan bakteri. Adapun hasil dari pelatihan tersebut dapat dilihat pada gambar di bawah ini “

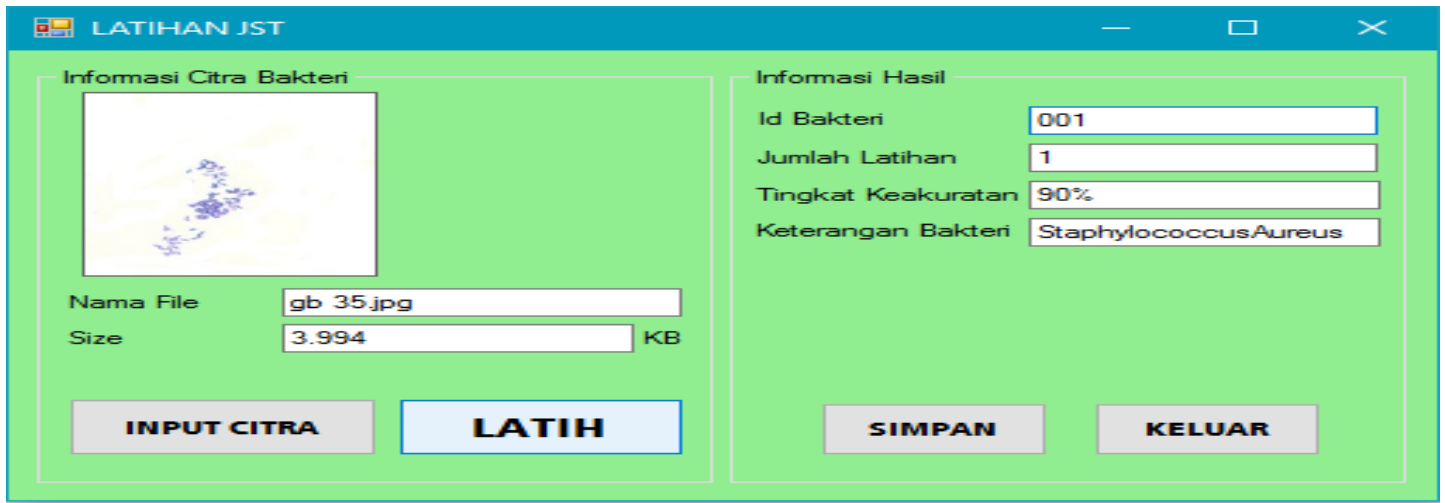

Gambar 4. Tampilan Hasil Latihan JST 
Berdasarkan pada gambar di atas, hasil yang didapatkan adalah sebuah keterangan tingkat keakuratan sebesar $90 \%$ dan keterangan bakteri berupa bakteri staphylococcusAureus. Hasil latihan ini disimpan kedalam databse aplikasi yang kemudian akan dicocokan nilainya dengan citra inputan proses dekteksi. Adapun hasil proses simpan seperti gambar di bawah ini :

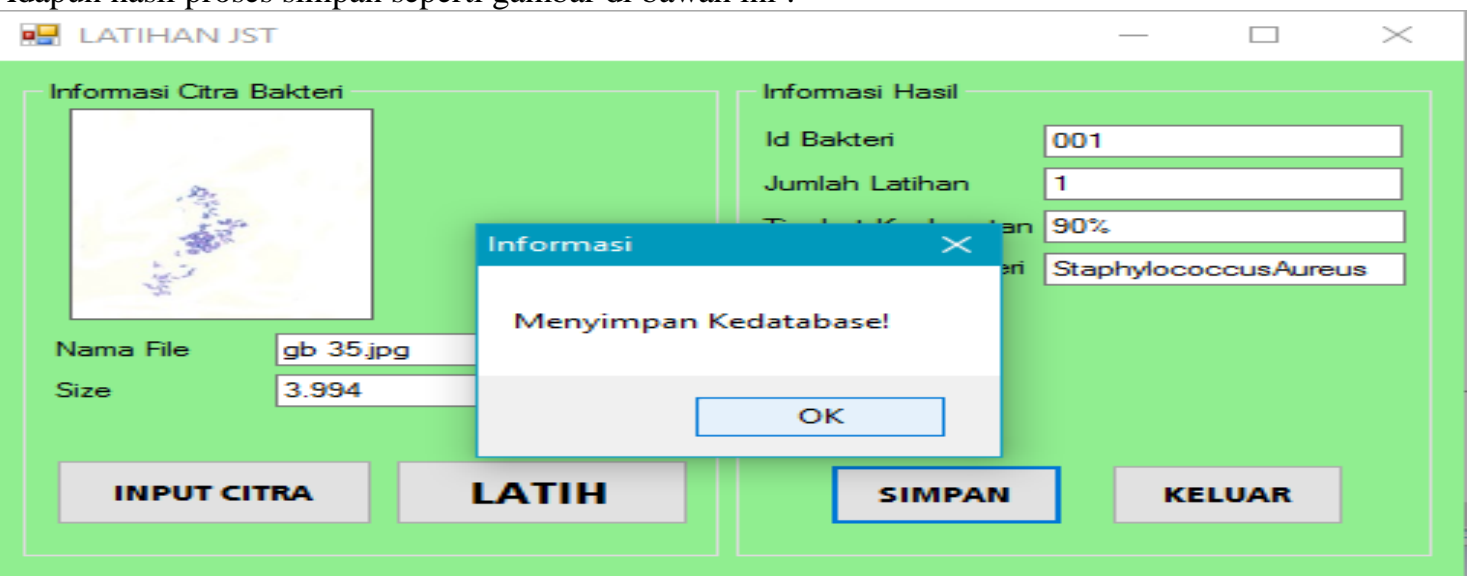

Gambar 5. Tampilan Proses Simpan Hasil Latihan JST

3. Tampilan Menu Deteksi

Tampilan menu deteksi adalah tampilan yang akan digunakan user untuk melakukan proses deteksi citra bakteri. Adapun tampilan menu deteksi yang telah dibangun menjadi aplikasi dapat dilihat pada gambar di bawah ini :

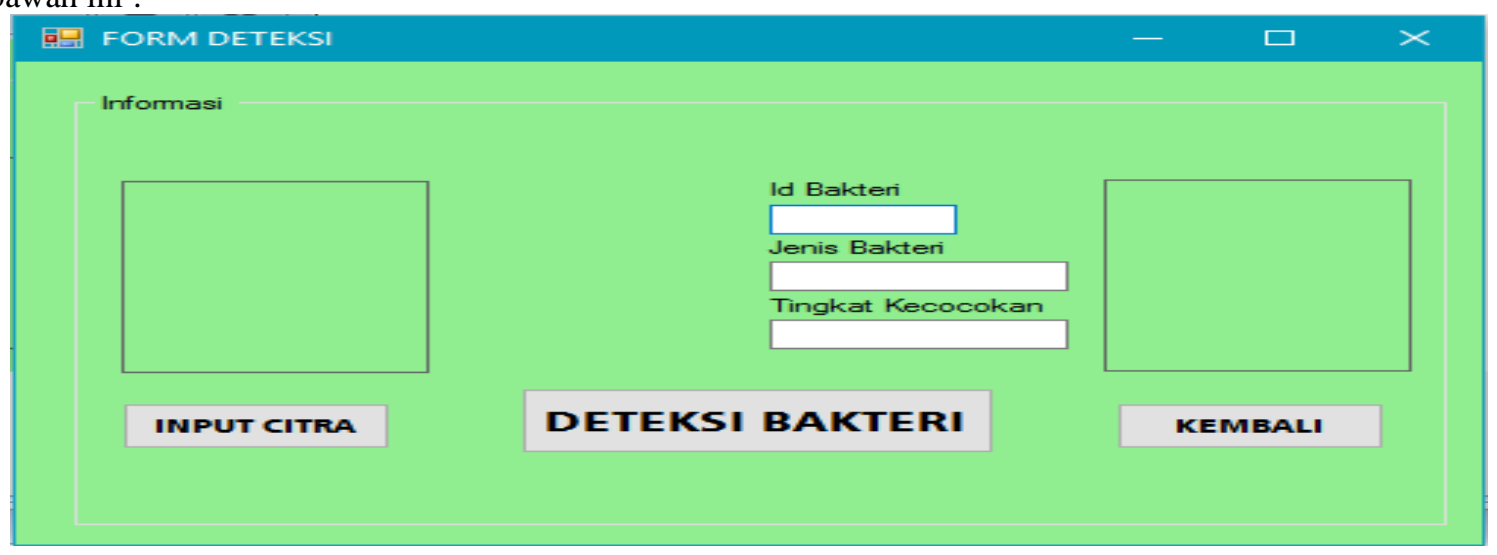

Gambar 6. Tampilan Menu Deteksi Bakteri

Berdasarkan pada gambar di atas, untuk memulai proses deteksi citra bakteri, user harus memilih citra bakteri yang akan dideteksi di direktori komputer dengan memilih button "INPUT CITRA". Adapun hasil pemilihan citra yang akan dideteksi bakterinya dapat dilihat pada gambar sebagai berikut :

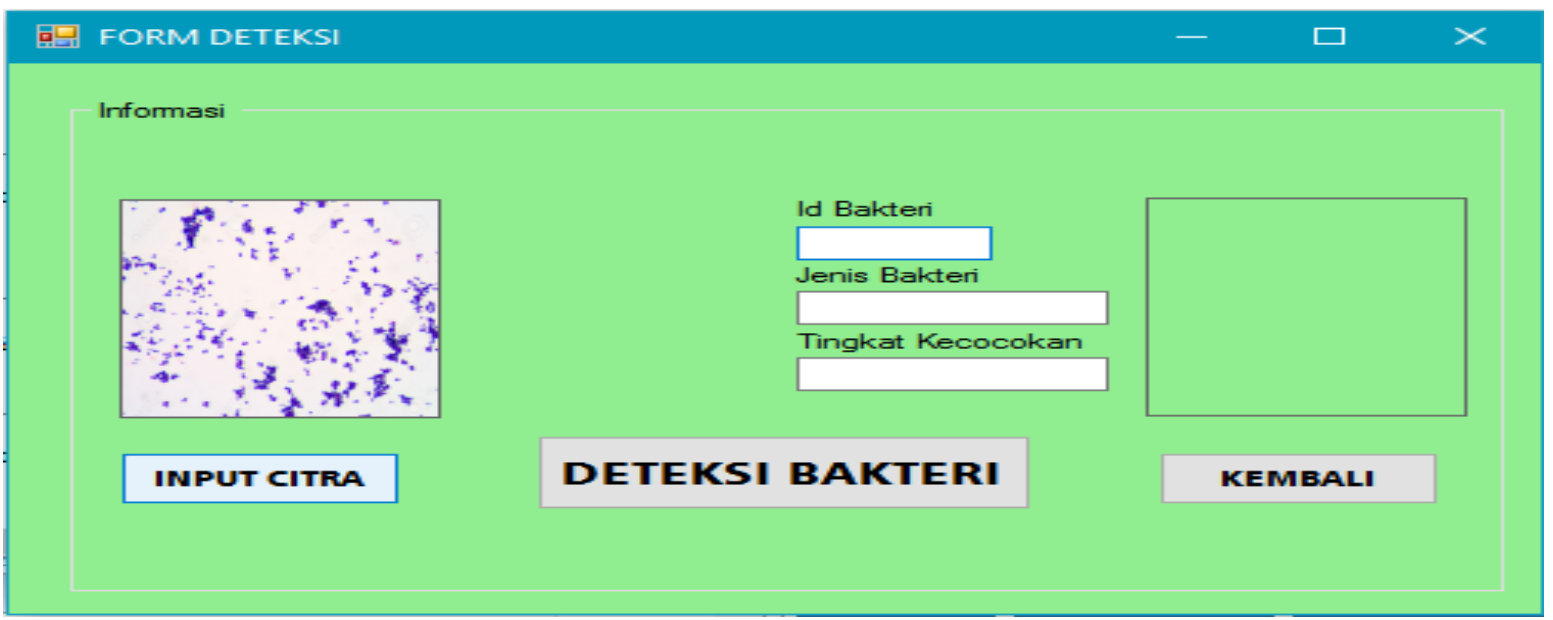

Gambar 7. Tampilan Citra Bakteri Yang Akan Dideteksi 
Berdasarkan pada gambar di atas, citra yang akan dideteksi bakterinya telah diiputkan kedalam aplikasi. Proses untuk melakukan deteksi bakteri menggunakan algoritma Backpropagation dilakukan dengan memilih button "DETEKSI BAKTERI".

Tampilan output adalah tampilan proses deteksi citra bakteri yang diinputkan oleh user. Pada proses deteksi, citra bakteri yang akan dideteksi, dicocokan dengan citra hasil pelatihan yang tersimpan didalam database saat proses latihan JST. Adapun hasil dari pecocokan deteksi bakteri pada citra yang inputkan dijabarkan pada gambar sebagai berikut :

1. Proses Deteksi Bakteri 1

Proses deteksi bakteri di dalam citra digital menggunakan algoritma Backpropagation terlebih dahulu dilakukan dengan mengiputkan citra bakteri yang akan dideteksi bakteri StaphylococcusAureus sebagai berikut

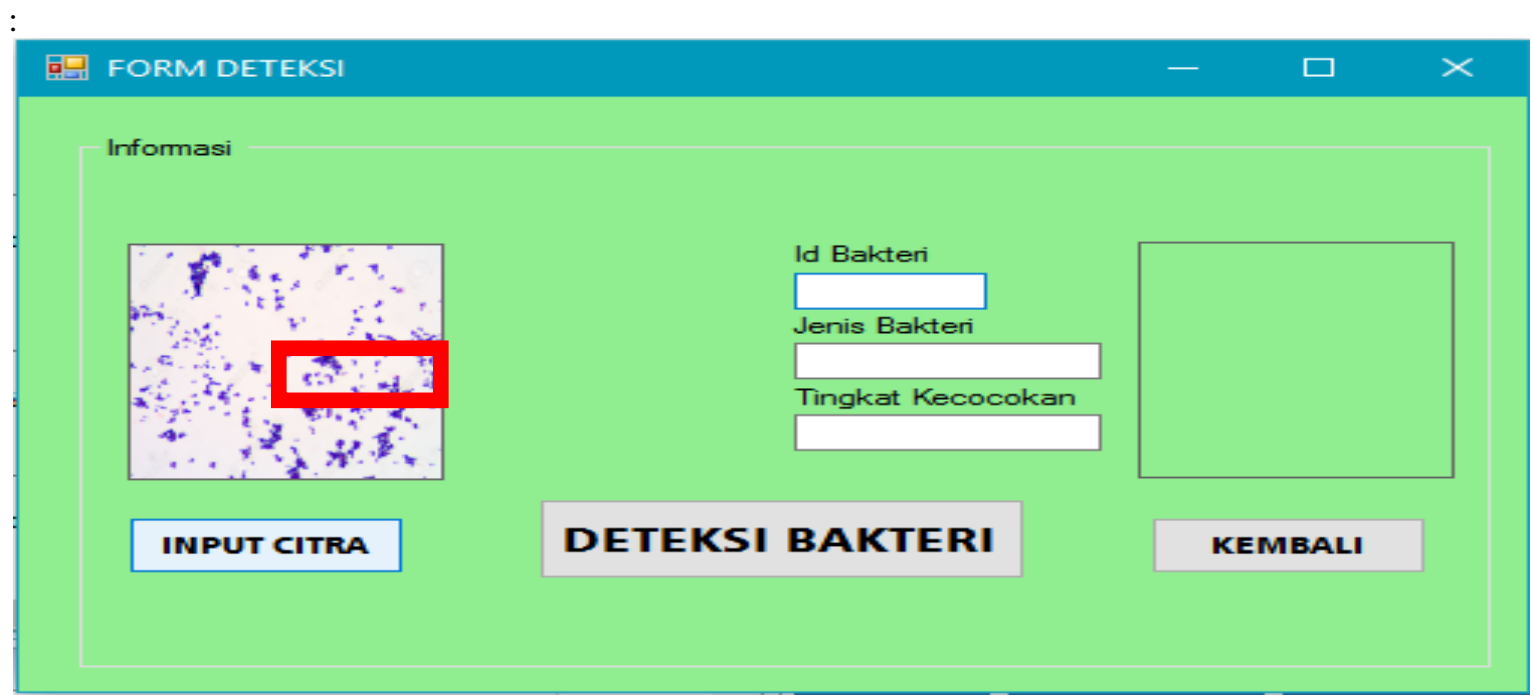

Gambar 8. Proses Penginputan Citra Bakteri

Berdasarkan pada gambar di atas, proses pertama terlebih dahulu menginputkan citra bakteri yang akan di deteksi dengan memilih button "INPUT CITRA". Citra bakteri yang diinputkan akan di deteksi sistem aplikasi dengan menekan button "DETEKSI BAKTERI" seperti di bawah ini :

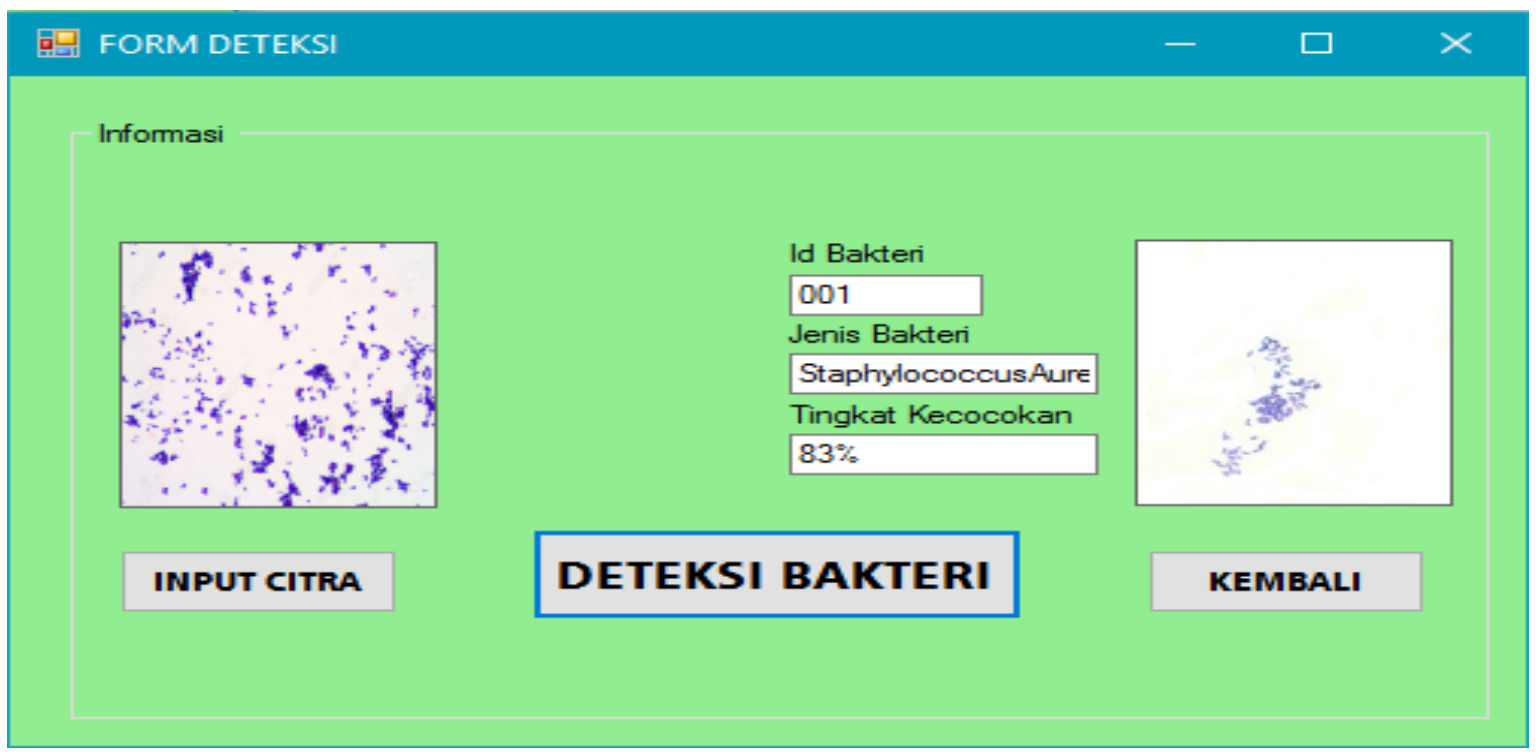

Gambar 9. Proses Deteksi Bakteri StaphylococcusAureus

Berdasarkan pada gambar 9. di atas, didapati hasil proses deteksi bakteri dengan algoritma bakcpropagation. Hasil keterangan yang didapat dengan citra bakteri yang diinputkan pada gambar di atas adalah jenis bakteri yaitu StaphylococcusAureus dengan kode 001 dan tingkat kecocokan $83 \%$.

Adapun hasil pengujian dari deteksi bakteri StaphylococcusAureus dengan sampel citra bakteri menggunakan algoritma Backpropagation dapat dilihat pada tabel di bawah ini :

Tabel 1. Hasil Pengujian

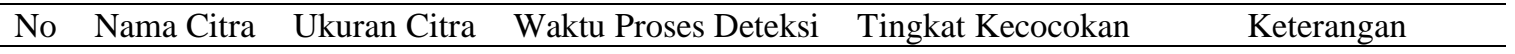




\begin{tabular}{lllcll}
\hline 1 & Sampel 1 & $120 \times 111$ & 8 Detik & $83 \%$ & StaphylococcusAureus \\
2 & Sampel 2 & $320 \times 170$ & 15 Detik & $78 \%$ & StaphylococcusAureus \\
\hline
\end{tabular}

\section{KESIMPULAN}

Berdasarkan hasil dari implementasi sistem yang telah dilakukan pada bab sebelumnya, dapat diambil kesimpulan bahwa:

1. Proses deteksi menggunakan perangkat lunak yang telah dibangun dapat dilakukan dengan baik. Proses tersebut dilakukan dengan mencocokan nilai vektor Backpropagation citra latihan dengan citra yang akan dideteksi.

2. Algoritma Backpropagation dapat melakukan deteksi bakteri StaphylococcusAureus dengan tingkat kecocokan diatas $70 \%$ dan tingkat keakuratan diatas $80 \%$.

3. Waktu yang dibutuhkan untuk deteksi bakteri StaphylococcusAureus bervariasi. Hal ini dikarenakan ukuran pixel citra yang berbeda-beda.

\section{REFERENCES}

[1] Jawetz, E., J.L. Melnick., E.A. Adelberg., G.F. Brooks., J.S. Butel., dan S.A. Morse. 2004. Mikrobiologi Kedokteran. Terjemahan H.Hartanto \& R.N.Elferia. Edisi ke-23. Penerbit Buku Kedokteran EGC. Jakarta

[2] Delimunthe, F.H., 2016. Perancangan Aplikasi Mengidentifikasi Penyakit Mata Dengan Menggunakan Metode Backpropagation. Jurnal Ris

[3] Rahayu, D., Wihandika, R.C., Perdana, R.,S. 2018. Implementasi Metode Backpropagation Untuk Klasifikasi Kenaikan Harga Minyak Kelapa Sawit. Jurnal Pengembangan Teknologi Informasi dan Ilmu Komputer. Vol. 2, (4).

[4] Wuryandari, M. D., \& Afrianto, I. (2012). Perbandingan Metode Jaringan Syaraf Tiruan Backpropagation dan Learning Vector Quantization pada Pengenalan Wajah. Jurnal Komputer dan Informatika (KOMPUTA) Universitas Komputer Indonesia, Edisi. I, Vol. 1 ,

[5] Koes Irianto. 2006. Mikrobiologi Menguak Dunia Mikroorganisme. Jilid 2.Jakarta.

[6] Syuhada, 2015. Realisasi Pengenalan Plat Nomor Kendaraan Dengan Metode Histogram Citra Dan Jaringan Syaraf Tiruan Backpropagation. Skripsi Universitas Lampung Bandar Lampung

[7] Russ J.C., 2002, The image Processing Handbook, Third Edition. CRC Press, CRC Press LLC.

[8] Putra., D., Pengolahan Citra Digital, Penerbit Andi, Yogyakarta, 2013.

[9] Munir, R., 2004, Pengolahan Citra Digital dengan Pendekatan Algoritmik, Bandung: Informatika.

[10] Fitryadi, K., \& Sutikno. (2016). Pengenalan Jenis Golongan Darah Menggunakan Jaringan Syaraf Tiruan Perceptron. Jurnal Masyarakat Informatika, Universitas Diponegoro, Vol. 7 No. 1, ISSN: 2086-4930,

[11] Puspitaningrum, D.. 2006. Pengantar Jaringan Syaraf Tiruan. Yogyakarta: Penerbit Andi.

[12] Entin, (12,Jan.2013). Available : http://entin.lecturer.pens.ac.id

[13] Tarik, H., Kodad, M., \& Miloud, J. E. (2014). Digital Movements Images Restoring by Artificial Neural Netwoks. Computer Science and Engineering, DOI: 10.5923

[14] Hermawan, 2006, Jaringan Saraf Tiruan Teori dan Aplikasi Yogyakarta: Andi

[15] Kusmaryanto, 2014. Jaringan Saraf Tiruan Backpropagation untuk Pengenalan Wajah Metode Ekstraksi Fitur Berbasis Histogram. Jurnal EECCIS Vol. 8, (2)

[16] Redjeki, S. (2013). Perbandingan Algoritma Backpropagation dan K-Nearest Neighbor (K-NN) untuk Identifikasi Penyakit. Seminar Nasional Aplikasi Teknologi Informasi (SNATI), ISSN: 1907-5022

[17] Siang, Jong Jek. 2005. Jaringan Saraf Tiruan dan Pemorogramannya Menggunakan Matlab. Yogyakarta :ANDI 